\title{
COMPUTER-ASSISTED COLLABORATIVE WRITING AND STUDENTS' PERCEPTIONS OF GOOGLE DOCS AND WIKIS: A REVIEW PAPER
}

\author{
Husam Masaoud Alwahoub, Mohd Nazri Latiff Azmi, Mohammad Halabieh \\ Universiti Sultan Zainal Abidin (UniSZA), Terengganu, Malaysia \\ E-mail: husam.m.alwahoub@gmail.com
}

Received: 05 May 2020

Accepted: 17 May 2020

\begin{abstract}
Computer-assisted collaborative writing has been gradually employed in L2 and FL contexts due to the introduction of Web 2.0 applications and tools (i.e., Google Docs and wikis) and its benefits in developing learners' writing skills. Accordingly, extensive literature that dealt with computer-assisted collaborative learning and learners' perceptions towards this activity has been condensed on shelves by time passing. Thus, a review of former studies over the recent decade is called forth aiming to ameliorate the difficulties of reaching this literature and to awaken broadened knowledge in this promising area. This paper reviewed and discussed about 40 relevant articles published from 2011 to 2019 that dealt with computer-assisted collaborative writing using Web 2.0 tools, precisely Google Docs and wikis, and learners' perceptions towards this activity (computer-assisted collaborative writing) and tools. All the articles were selected according to specific criteria, where only a true collaborative writing peer-reviewed articles were selected. After that, two main themes were synthesized: (a) collaborative writing outcomes and (b) students' perceptions, and specific research components in relation to each theme were further reviewed and summarized using illustrative tables. Drawing on the review of this literature, the researchers discuss pedagogical implications in terms of technology integration and writing development and address future research directions including systematically reviewing this topic with teachers' perceptions of computer-assisted collaborative writing.
\end{abstract}

Keywords: Synchronous/Asynchronous Collaborative Writing, Computer-Assisted Collaborative Writing, Google Docs, Wikis, CALL

\section{Introduction}

Computer-supported collaborative learning plays a pivotal role in language teaching due to its high significance. By applying computer-supported collaborative writing, a positive effect on students' writing was demonstrated, in particular, writing connectedness (Streetman, 2018). However, through time pass, various terms were coined in the different studies; thus, academic research on computer-assisted collaborative learning is a little bit problematic. The most common term through literature is computer-supported collaborative learning. It was used by many contemporary researchers such (Kwon et al., 2014; Goodyear et al., 2014, Zhang et al., 2014; Jeong et al., 2016; Koenig et al., 2017; Bodemer et al., 2018). Other studies referred to it as: computer-based collaborative learning (Littleton, 1999), computer-assisted cooperative learning (Johnson et al., 1986; AbuSeileek, 2012), computer- 
supported cooperative learning (McConnell, 2014; Newman et al., 1997), computersupported group learning (Newman et al., 1995), or computer-mediated collaborative learning (Alavi, 1994; Warschaue, 1997; Beatty \& Nunan 2004; Li, 2018). The researchers in this paper used the term "computer-assisted collaborative writing" as the term "computerassisted" is more globally recognised as part of the Computer-Assisted Collaborative Learning (CALL) terminology.

During the last four decades, second language (L2) writing has grabbed researchers' interest and attention. In the 1960s, the theoretical and educational development of L2 writing led to the opening of new areas of second applied linguistics and language acquisition. The integrative field became the main emphasis of many $L 2$ researchers examining theoretical, pedagogical, functional, and methodological perspectives of ESL and EFL literacy. One of the most crucial issues that have been discussed in recent times is the possibility of integrating technology in teaching English writing. To date, a considerable amount of research was published about computer-assisted collaborative writing, as an effective instructional activity, and it has been extensively supported by many experimental research studies (Aljafen, 2008). Consequently, collaborative writing has been extensively implemented in L2 and FL contexts during the last decades because it affords better opportunities for the learners to pool language resources cooperatively and co-construct writing and knowledge via scaffolded interactions (Donato, 1994; Swain, 1995).

Former studies have reported many affordances of collaborative writing such as enhanced audience awareness (Storch, 2012), better environments to apply new-learned knowledge (Hirvela, 1999), and improved language forms and discourse (DiCamilla \& Anton, 1997; Swain \& Lapkin, 1998). Storch (2013) defined collaborative writing as an activity in which learners negotiate meaning, interact, and mutually produce decisions during the writing process and construct a single text with joint responsibility and co-ownership. According to this definition, computer-based collaborative writing refers to the collaborative writing activity in which students co-construct tasks, negotiate meaning, co-revise texts, and jointly produce a single online text through collaborative efforts using web-based technology tools, such as Google Docs and wikis.

The first-generation of web applications (Web 1.0) were mostly used to facilitate discussions in the computer-mediated communication (CMC) context such as chat rooms and discussion boards. However. Web 2.0 applications supports the writing process entirely, where it starts with task discussions and languaging then text co-construction, revising and editing until the last writing product. However, after the development that Web 2.0 has achieved using tools such as Google Docs and wikis that provides participation, teamwork and collaboration at an extraordinary level, more attention was paid to computer-assisted collaborative writing in second and foreign language settings due to its features of writing interactivity, composing reflection and the independence of time and space.

Thus, research on computer-based collaborative writing continues to expand during recent years. A literature review of these studies is therefore necessary and crucial, which aims to facilitates future research, produce expanded knowledge and afford new perceptions about this promising topic. In this study, the authors review this rich literature about computer-based collaborative writing and learners' perceptions towards synchronous collaborative writing and web-based tools (i.e., Google Docs and wikis) aiming to make this topic more attainable and approachable for future research as it is clear that more studies are being conducted about technology implementation in education to enhance the writing skill. 


\section{Research Method}

Aiming to select articles to review in this paper, the author went through relevant journal articles published over the last decade searching via Google Scholar, Science Direct, and ProQuest. Precisely, the author conducted advanced search on Google Scholar, using the combination of key words 'collaborative writing', 'computer-assisted/mediated collaborative writing', 'synchronous collaborative writing', 'Google Docs', 'wikis', and 'computer-mediated communication', with the publication dates set between 2011 and 2019. After that, the author screened all the articles based on titles and abstracts aiming to limit the selection of articles for inclusion according to the following criteria: (1) studies published in recognized peerreviewed CALL-centred journals and (2) a true collaborative writing activity that used a Web 2.0 application and involved collaboration and a co-ownership of a single online or offline text. For example, Zou, Wang, \& Xing (2016) was excluded from the study because it addresses the task of peer response, which cannot be considered as collaborative writing in that peer response does not involve co-authorship of writing or include the entire writing processes which was defined by Storch (2013) as collaborative planning, joint writing, revision and editing. Accordingly, about forty relevant articles were thus selected for close review in this paper and reported according to the criteria set by the author.

\section{Results and Discussion}

In this paper, the author thoroughly reviewed about forty articles and presented the findings in relation to Web-based collaborative tool (i.e., Google Docs and wikis), collaborative writing outcomes, and how students perceived the collaborative writing activity and the online tools used through collaboration, with the help of illustrative tables. The authors aim to provide a clear picture of the current body of literature by depicting a detailed research about this topic.

\subsection{Collaborative Writing}

There is a growing interest in developing writing activities in language learning due to the vital role of written interaction in social networks in addition to the fact that writing can support second language learning (Storch, 2013). Recent research on collaborative writing became more popular than before as collaborative writing introduces a new dimension of social interaction (Sharples et al., 1993). Godwin (2018) agrees with this idea, particularly after recognizing writing as a social activity that leads to more interest in collaborative writing. In another study about collaborative writing in traditional non-technology settings, Storch (2005) concluded that the writing developed in-pair or in-group work helps to produce a higher level of accuracy than texts written individually. Besides, she explored collaborative writing patterns using transcribed peer talk and students' reflections, and she identified four patterns of face-to-face collaborative writing interactions: collaborative, dominant-dominant, dominant-passive, and expert-novice. Whereby, she resolved that pairs in the collaborative and the expert-novice patterns accomplished better in the writing tasks. Accordingly, her study showed that the patterns of peer interaction affected students' literacy outcomes (Storch, 2002).

Moreover, literature also showed a vital role of collaborative writing in enhancing students' writing accuracy. McDonough et al. (2018) compared the writing quality of collaborative and individual writing in a Thai EFL context and confirmed that texts that were written collaboratively were more accurate than texts that were written individually. These findings confirmed the results of other previous studies that also revealed improvement in 
learners' accuracy (Dobao 2012; Wigglesworth \& Storch, 2009; McDonough \& García, 2015; Storch \& Wigglesworth, 2007). In another study about Colombian EFL learners, that compared students' texts which were written collaboratively and those written individually, McDonough \& García (2015) found that collaborative texts were more accurate than individual ones. However, they also found that collaborative texts did not contain greater subordination or more words.

Bhowmik \& Hilman (2018) investigated collaborative peer writing, and they found that the learners were more aware of their writing abilities, strengths, and weaknesses through collaborative writing. Learners also valued the use of collaborative writing because they believe that it supports them in putting together their ideas and introduces them to the new and different writing styles of their peers.

\subsection{Computer-Assisted Collaborative Writing using Web 2.0 Tools}

In this section, the researchers shed light on the use of collaborative writing via computer, and they focus on the research that investigated synchronous collaborative writing using Google Docs and asynchronous collaborative writing using wikis because they are the most common and practical tools in Web 2.0. Moreover, these two tools are more accessible and offer immense features of word processing tools, team-work and interaction. Google Docs is a cloud-based tool related to the term shared documents as called by pervious researchers (Hofer, 2012) or word web-based processing tool (Kessler et al., 2012). Shared documents technology and wikis are interconnected. Certainly, Wikis seem to be thought the base of Web 2.0 due to their features of making websites editable using a flexible user interface. Hyland (2016) and Vandergriff (2016) concluded that the introduction of Web 2.0 applications made the creation, editing, and sharing of texts more accessible.

\subsubsection{Google Docs}

Google Docs provides updated features that are equivalent to many developing cloudbased word-processing tools which include synchronised editing, updating and automated saving. Besides, Google Docs can be used in synchronous and asynchronous modes. It also can be used by a single user or by individual users who can provide insights into the writing process smoothly and efficiently (Steinberger, 2017). Findings revealed many improvements of students writing after the use of Google Docs in collaborative writing and these results are divided into two groups: a) enhanced text quality, content, and organisation and b) enhanced writing performance and abilities.

\section{a) Enhanced Text Quality, Content, and Organization}

Yim et al. (2017) investigated synchronous collaborative writing and its effects on improving students writing quality, quantity, and style. They found that specific writing patterns (such as Divide and Conquer) appear to produce better text quality. Moreover, they also found that balanced participation and the peer-editing amount produced longer composition with better quality in content and evidence measures. Strobl (2014) studied the procedures and outcomes of collaborative and individual writing. Results showed that the collaborative groups scored better in text accuracy. Moreover, collaborative texts scored higher on content selection and organisation.

\section{b) Enhanced Writing Performance and Abilities}


Many studies revealed the positive impact of computer-based collaborative writing on enhancing students' performance. Seyyedrezaie et al. (2016) investigated the effect of the writing process in the Google Docs environment on the writing performance of Iranian EFL learners and found that Google Docs had an active role in developing the performance of students' writing. Liu \& Lan (2016) examined students' collaboration, motivation, and perception on the use of Google Docs, and their findings showed that the collaborators performed better in their writing, and they were more likely to be motivated to acquire knowledge and perceived the learning experience more positively than the individuals. Suwantarathip \& Wichadee (2014) investigated the impact of Google Docs on students' writing. It was shown that Google Docs was efficiently used to enhance the abilities of students' individual writing. Furthermore, the study also revealed that students who evaluated other peers' work using Google Docs developed more understanding of the writing activities. In a Saudi context, Mudawe (2018) investigated the instructional abilities of Google Docs as a collaborative tool to improve EFL and ESL students' writing. He found that Google Docs extends the opportunity of communication between students and their supervisor and that Google Docs improved their editing and revision of texts in a motivated environment. Futhermore, Ambrose and Palpanathan (2017) examined the use of Google Docs in enhancing students' writing. The analysis of writing samples showed that there was an enhancement in students' writing with the use of Google Docs, and they found that most of the students considered Google Docs to be a consistent tool in learning writing and they had a positive attitude towards it. Bikowski \& Vithanage (2016) explored the effect of in-class web-based collaborative writing tasks on second language writers' individual writing scores. Findings showed that the collaborators had statistically significant writing improvements in their individual writing, and the participants appreciated the collaborative in-class writing experiment.

\subsubsection{Wikis}

Wikis are mostly editable websites that can be modified by numerous users but not concurrently. Wikis are often believed to be better suited for asynchronous group writing projects because one user must wait for another user, who is editing the same page, to be able to add or modify other people's writing. Literature that investigated collaborative writing via wkis revealed many positive outcomes, so the researchers divided these results into two groups: a) enhanced writing quality and b) enhanced writing performance and competence.

\section{a) Enhanced Writing Quality}

Aljafen (2018) explored Wiki-based collaborative writing impact on male EFL students' writing performance compared with traditional collaborative writing classroom. Results showed that the collaborative wiki classroom scored higher in writing quantity and quality than the traditional classroom. Moreover, Li \& Zhu (2016) investigated links between group interactions and writing products in wiki writing. They found that the features of wiki interactions enhance the writing qualities and that students' combined efforts showed ingroup members' joint engagement in scaffolding strategies and language functions. These findings of Li \& Zhu were in line with Aydin \& Yildiz (2014) who studied how wikis promote collaborative writing for EFL students. They found that the use of wiki-based collaborative writing tasks led to more accurate use of grammatical structures and that participants' focus was on the meaning rather than on the task form. Alshalan (2016) explored the impacts of wikis on the writing performance. He found that wiki writing is a profitable approach in the 
ESL field and that the treatment group revealed a significant development in three variables (grammar, mechanics, and vocabulary), but it failed to reveal a significant difference in overall and content variables.

\section{b) Enhanced Writing Performance and Competence}

In this context, Wang (2015) supported the positive impacts of collaborative writing after using wikis as he found that students who participated in the collaborative writing tasks improved in business writing and valued the challenge of this activity. Furthermore, the findings also indicated that wikis stimulate students' interest while learning a language and enhance the development of their writing abilities. Besides, Aydin \& Yildiz (2014) also revealed that after the use of wiki-based collaborative writing tasks students believed that their writing performance had a development, and they had positive practices during writing. Furthermore, Lin (2014) explored students' and teachers' attitudes toward collaborative writing using wikis. Findings revealed that students demonstrated a development in students' writing attitudes after using collaboration treatment. Moreover, the study also found that students showed a higher interest in collaborative writing compared to writing on a traditional paper. Li \& Kim (2016) examined two ESL groups' interactions during two collaborative writing tasks that used wikis. Results showed that the two ESL groups working on the same writing tasks and wikis had extremely different strategies of collaboration and that there was a change in patterns occurred across two tasks. They discussed these aspects in connection with the scaffolding flexibility taking place within small collaborative groups.

Table 1: Summary and Main Findings of Collaborative Writing Implementation

\begin{tabular}{|c|c|c|c|}
\hline Article /Study & Technology & Themes & Main Findings \\
\hline Strobl (2014) & Google Docs & $\begin{array}{l}\text { Processes and } \\
\text { outcomes of } \\
\text { individual and } \\
\text { collaborative writing }\end{array}$ & $\begin{array}{l}\text { Students had better text } \\
\text { accuracy and higher } \\
\text { scores on content } \\
\text { selection and } \\
\text { organisation }\end{array}$ \\
\hline $\begin{array}{l}\text { Suwantarathip } \\
\text { \& Wichadee } \\
\text { (2014) }\end{array}$ & Google Docs & $\begin{array}{l}\text { The impact of Google } \\
\text { Docs on students' } \\
\text { writing }\end{array}$ & $\begin{array}{l}\text { - Students developed } \\
\text { their writing abilities and } \\
\text { had more understanding } \\
\text { of the writing process. }\end{array}$ \\
\hline Lin (2014) & Wiki & $\begin{array}{l}\text { Students' and } \\
\text { teachers' attitudes } \\
\text { toward collaborative } \\
\text { writing using wikis }\end{array}$ & $\begin{array}{l}\text { There was an } \\
\text { improvement in writing } \\
\text { attitudes and higher } \\
\text { interest in collaborative } \\
\text { writing }\end{array}$ \\
\hline $\begin{array}{l}\text { Aydin \& Yildiz } \\
\text { (2014) }\end{array}$ & Wiki & $\begin{array}{l}\text { The use of wikis to } \\
\text { promote } \\
\text { collaborative EFL } \\
\text { writing }\end{array}$ & $\begin{array}{l}\text { Students were more } \\
\text { accurate at using } \\
\text { grammatical structures }\end{array}$ \\
\hline Wang (2015) & Wiki & $\begin{array}{l}\text { The positive impacts } \\
\text { of collaborative } \\
\text { writing using wikis }\end{array}$ & $\begin{array}{l}\text { Wikis stimulated } \\
\text { students' interest in } \\
\text { language learning and } \\
\text { developed their writing }\end{array}$ \\
\hline
\end{tabular}




\begin{tabular}{|c|c|c|c|}
\hline & & & $\begin{array}{l}\text { competencies and } \\
\text { collaboration abilities } \\
\text { and they had mastery in } \\
\text { business writing. }\end{array}$ \\
\hline $\begin{array}{l}\text { Bikowski \& } \\
\text { Vithanage } \\
\text { (2016) }\end{array}$ & Google Docs & $\begin{array}{l}\text { The effect of in-class } \\
\text { web-based } \\
\text { collaborative writing } \\
\text { tasks on second } \\
\text { language writers' } \\
\text { individual writing }\end{array}$ & $\begin{array}{l}\text { - There were } \\
\text { improvements in } \\
\text { students' individual } \\
\text { writing }\end{array}$ \\
\hline Li \& Zhu (2016) & Wiki & $\begin{array}{l}\text { Group interactions } \\
\text { and writing products } \\
\text { in wiki }\end{array}$ & $\begin{array}{l}\text { Students enhanced } \\
\text { qualities of wiki writing } \\
\text { and had a better } \\
\text { scaffolding strategy }\end{array}$ \\
\hline Alshalan (2016) & Wiki & $\begin{array}{l}\text { The impacts of wikis } \\
\text { on the writing } \\
\text { performance of ESL } \\
\text { students }\end{array}$ & $\begin{array}{l}\text { - Students had } \\
\text { improvements in three } \\
\text { dependent variables } \\
\text { (grammar, vocabulary, } \\
\text { and mechanics) }\end{array}$ \\
\hline Li \& Kim (2016) & Wiki & $\begin{array}{l}\text { ESL groups' } \\
\text { interactions during } \\
\text { two collaborative } \\
\text { writing in wikis }\end{array}$ & $\begin{array}{l}\text { - Students developed } \\
\text { different strategies of } \\
\text { collaboration }\end{array}$ \\
\hline $\begin{array}{l}\text { Seyyedrezaie et } \\
\text { al. (2016) }\end{array}$ & Google Docs & $\begin{array}{l}\text { The effect of the } \\
\text { writing process in } \\
\text { Google Docs } \\
\text { environment on } \\
\text { Iranian EFL learners' } \\
\text { writing performance. }\end{array}$ & $\begin{array}{l}\text { Participants developed } \\
\text { their writing } \\
\text { performance }\end{array}$ \\
\hline Liu \& Lan (2016) & Google Docs & $\begin{array}{l}\text { Students' } \\
\text { collaboration, } \\
\text { motivation, and } \\
\text { perception on the } \\
\text { use of Google Docs }\end{array}$ & $\begin{array}{l}\text { - Students were } \\
\text { motivated to acquire } \\
\text { knowledge, and their } \\
\text { performance improved }\end{array}$ \\
\hline Yim et al. (2017) & Google Docs & $\begin{array}{l}\text { Synchronous } \\
\text { collaborative writing }\end{array}$ & $\begin{array}{l}\text { - Students had a better } \\
\text { text quality }\end{array}$ \\
\hline $\begin{array}{l}\text { Ambros \& } \\
\text { Palpanathan } \\
(2017)\end{array}$ & Google Docs & $\begin{array}{l}\text { The use of Google } \\
\text { Docs in enhancing } \\
\text { students' writing }\end{array}$ & $\begin{array}{l}\text { - Students' writing was } \\
\text { developed }\end{array}$ \\
\hline Mudawe (2018) & Google Docs & $\begin{array}{l}\text { Google Docs: } \\
\text { Potentials and } \\
\text { Promises for } \\
\text { Scaffolding } \\
\text { Supervisory } \\
\text { Pedagogical Practices } \\
\text { of EFL/ ESL Students' } \\
\text { Writing }\end{array}$ & $\begin{array}{l}\text { - Students improved their } \\
\text { editing and revision of } \\
\text { texts in a motivated } \\
\text { environment. }\end{array}$ \\
\hline
\end{tabular}




\begin{tabular}{llll}
\hline Aljafen (2018) Wiki & $\begin{array}{l}\text { The impact of } \\
\text { collaborative writing } \\
\text { on male EFL students }\end{array}$ & $\begin{array}{l}\text { Students had higher } \\
\text { scores in writing } \\
\text { quantity and quality }\end{array}$
\end{tabular}

\subsection{Students' Perceptions of Computer-Assisted Collaborative Writing}

Extensive research had been conducted on students' perceptions of collaborative writing using various instruments and tools. The majority of the findings pointed to the positive perceptions and advantages of combining technology in collaborative writing instruction, but other studies had less-positive perceptions about these disadvantages.

\section{a) Positive Perceptions}

Seyyedrezaie et al. (2016) examined students' perceptions of Google Docs. Students' responses showed a positive attitude towards the implication of Google Docs as a factor causing an enhancement in their writing performance. Liu \& Lan (2016) examined students' perception of Google Docs. The findings of the study showed that the collaborators were more positive than the individuals to perceive the learning experiences and more motivated to obtain knowledge. Moreover, the results of this study also suggest that Google Docs has a vital role in improving students' enthusiasm and motivation. Li et al. (2011) explored primary school students' and teacher's perspectives of collaborative writing and they found that students' writing attitudes had improvement after engaging in collaborative writing activities. Furthermore, students considered collaborative writing as advantageous because it expanded the reading audience of their writings and increased interactions within the collaborative group. In a tertiary level, Zhou et al. (2012) claimed that web-based technology drastically changed the collaborative procedures of participating in college undergraduates. In his study, participants agreed that Google Docs helped them communicate effortlessly and efficiently. However, such promising outcomes would not be attainable without getting students accustomed to technology use because the understanding of the tools has a critical role in student perception of collaboration (Brodahl, \& Hansen, 2014). Suwantarathip \& Wichadee (2014) found that students were more confident in sharing their ideas with others while using Google Docs and collaborative writing. Kessler et al. (2012) reported that students in their study admit that every member played a vital role in this collaborate experience. Kennedy \& Miceli (2013) also reported that students had a sense of community while working together using online technology and web-based tools. Aljafen (2018) explored students' perceptions of writing collaboration, and his qualitative analysis of participants interviews showed that both treatments had positive responses toward collaborative writing in terms of its process writing, ease of use, and usefulness. Lin (2014) investigated students' and teachers' attitudes toward collaborative writing using wikis. Findings revealed that students' writing attitudes showed a development after engaging in the collaborative activity, and that students had positive perceptions on the use of online collaborative writing environment.

\section{b) Less Positive Perceptions}

On the other hand, other results were less positive regarding students' perceptions, and they seem to reveal students' lack of confidence while or after dealing with digital tools. Zhu (2012) found that cultural differences directly influenced students' beliefs about the digital environment after comparing students' contributions in the online discussion in their countries. Li \& Kim (2016) explored the dynamic interactions across ESL collaborative writing tasks. They found that two groups working on the same tasks in a wiki space performed 
unexpectedly different patterns of collaboration and that they changed across two tasks within each group. Strobl's (2014) analysis showed that collaboration failed in one group of his study because of members' free-riding attitudes, also called "social loafing" (Storch, 2013, p.124). Aljafen (2018) explored students' attitudes of writing collaboratively were significant but not for all the measurements. Students' responses were similar in writing performance, anxiety, and future use.

Table 2: Summary of Collaborative Writing Perceptions

\begin{tabular}{|c|c|}
\hline Article / Study & Main Findings \\
\hline Li et at. (2011) & $\begin{array}{l}\text { - Students perceived collaborative writing as } \\
\text { advantageous }\end{array}$ \\
\hline Zhou et al. (2012) & $\begin{array}{l}\text { - Google Docs helped them communicate } \\
\text { effortlessly with others and write with less } \\
\text { anxiety }\end{array}$ \\
\hline Kessler et al. (2012) & $\begin{array}{l}\text { Students felt that each member of the group } \\
\text { had contributed and had a valuable role when } \\
\text { working synchronously }\end{array}$ \\
\hline Zhu (2012) & $\begin{array}{l}\text { - Students had strong evidence that cultural } \\
\text { differences directly influenced their perceptions }\end{array}$ \\
\hline Kennedy \& Miceli (2013) & $\begin{array}{l}\text { Students had a stronger sense of community } \\
\text { among those working together via online } \\
\text { technology }\end{array}$ \\
\hline $\begin{array}{l}\text { Suwantarathip \& } \\
\text { Wichadee (2014) }\end{array}$ & $\begin{array}{l}\text { - The student revealed more confidence in } \\
\text { sharing their ideas with others }\end{array}$ \\
\hline Lin (2014) & $\begin{array}{l}\text { - Students had a positive perception of the use of } \\
\text { online collaborative writing environment }\end{array}$ \\
\hline Strobl (2014) & $\begin{array}{l}\text { - Collaboration failed in one group of his study } \\
\text { because of members' free-riding attitudes }\end{array}$ \\
\hline Seyyedrezaie et al. (2016) & $\begin{array}{l}\text { - Students had positive attitudes towards the } \\
\text { implication of Google Docs }\end{array}$ \\
\hline Liu \& Lan (2016) & $\begin{array}{l}\text { - Collaborators positively perceived the learning } \\
\text { experience and to be more motivated to obtain } \\
\text { knowledge. } \\
\text { - Google Docs played a vital role in improving } \\
\text { students' enthusiasm and motivation }\end{array}$ \\
\hline Li \& Kim (2016) & $\begin{array}{l}\text { - They found that two ESL groups working on } \\
\text { identical tasks in the same wiki space enacted } \\
\text { unexpectedly different patterns of collaboration }\end{array}$ \\
\hline Aljafen (2018) & $\begin{array}{l}\text { Students had positive responses toward } \\
\text { collaborative writing in terms of its usefulness, } \\
\text { ease of use, and process writing }\end{array}$ \\
\hline Aljafen (2018) & $\begin{array}{l}\text { - Students' responses were similar in writing } \\
\text { performance, writing apprehension, and future } \\
\text { use. }\end{array}$ \\
\hline
\end{tabular}




\section{Conclusions and Future Directions}

This paper reviewed computer-assisted collaborative writing using Web 2.0 tools and learners' perceptions about them. The archives revealed that computer assisted collaborative writing had a positive impact on developing students' writing quality (Strobl, 2014: Yim et al., 2017; Aljafen, 2018; Li \& Zhu, 2016; Aydin \& Yildiz, 2014), and writing performance (Seyyedrezaie et al., 2016: Liu \& Lan, 2016; Suwantarathip \& Wichadee, 2014; Suwantarathip \& Wichadee, 2014; Ambrose \& Palpanathan, 2017; Bikowski \& Vithanage, 2016; Wang, 2015; Aydin \& Yildiz, 2014; Lin, 2014; Li \& Kim, 2016). Moreover, many studies revealed positive perceptions of collaborative writing (Seyyedrezaie et al., 2016; Liu \& Lan, 2016; Li et at., 2011; Zhou et al., 2012; Suwantarathip \& Wichadee; 2014; Kessler et al., 2012; Kennedy \& Miceli, 2013; Aljafen, 2018; Lin, 2014). Still, a few studies showed less-positive findings and perceptions and revealed no difference between students who wrote collaboratively and others who used traditional or face-to-face writing (Zhu, 2012; Li \& Kim, 2016; Strobl, 2014; Aljafen, 2018).

After reviewing former literature addressing computer-assisted collaborative writing outcomes and students' perceptions, the author recommends the implementation of computer-based collaborative writing in L2 and FL contexts, where the teachers and instructors ought to prudently design writing tasks that are motivating, effective and extremely related to the objectives of the course. Moreover, he recommends the integration of technology-based instructions in education as many studies confirmed its validity in enhancing learners' individual writing and the learning environment in general.

Due to the growing usage of computer technologies, research on computer-based collaborative writing is likely to increase more in the coming decade. Accordingly, it is recommended for further researches to systematically review computer-assisted collaborative writing outcomes and perceptions, especially articles that investigated it in the mainstream K-12 context. Moreover, reviewing literature that explored teachers' perceptions of computer-assisted collaborative writing and Web 2.0 tools and applications is highly advised.

\section{References}

AbuSeileek, A. F. (2012). The effect of computer-assisted cooperative learning methods and group size on the EFL learners' achievement in communication skills. Computers \& Education, 58(1), 231-239.

Alavi, M. (1994). Computer-mediated collaborative learning: An empirical evaluation. MIS quarterly, 159-174.

Aljafen, B. S. (2018). TRADITIONAL VS. WIKI: SAUDI STUDENTS' PERFORMANCE IN AND PERCEPTIONS OF COLLABORATIVE WRITING IN A WIKI.

Alshalan, A. M. (2016). The Effects Of Wiki-Based Collaborative Writing On Esl Student's Individual Writing Performance.

Ambrose, R. M., \& Palpanathan, S. (2017). Investigating the Effectiveness of ComputerAssisted Language Learning (CALL) Using Google Documents in Enhancing Writing--A Study on Senior 1 Students in a Chinese Independent High School. IAFOR Journal of Language Learning, 3(2), 85-112.

Aydin, Z., \& Yildiz, S. (2014). Using wikis to promote collaborative EFL writing. Language Learning \& Technology 18(1), 160-180. Retrieved from http://llt.msu.edu/issues/february2014/aydinyildiz.pdf 
Bhowmik, S. K., Hilman, B., \& Roy, S. (2018). Peer collaborative writing in the EAP classroom: Insights from a Canadian postsecondary context. TESOL Journal, e393.

Bikowski, D., \& Vithanage, R. (2016). Effects of web-based Collaborative writing on individual L2 writing development. Language Learning \& Technology, 20(1), 79-99.

Bodemer, D., Janssen, J., \& Schnaubert, L. (2018). Group awareness tools for computersupported collaborative learning. In International handbook of the learning sciences(pp. 351-358). Routledge.

Brodahl, C., \& Hansen, N. K. (2014). Education students' use of collaborative writing tools in collectively reflective essay papers. Journal of Information Technology Education: Research, 13, 91-120. Retrieved from https://www.informingscience.org/Publications/1960

DiCamilla, F., \& Anton, M. (1997). The function of repetition in the collaborative discourse of L2 learners. The Canadian Modern Language Review, 53, 609-633.

Dobao, A. F. (2012). Collaborative writing tasks in the L2 classroom: Comparing group, pair, and individual work. Journal of second language writing, 21(1), 40-58.

Donato, R. (1994). Collective scaffolding in second language learning. In J.P. Lantolf \& G. Appel (Eds.), Vygotskian approaches to second language research (pp. 33-56). Norwood, NJ: Ablex.

Hirvela, A. (1999). Collaborative writing instruction and communities of readers and writers. TESOL Quarterly, 8(2), 7-12.

Godwin-Jones, R. (2018). Second language writing online: An update. Language Learning \& Technology, 22(1), 1-15.

Goodyear, P., Jones, C., \& Thompson, K. (2014). Computer-supported collaborative learning: Instructional approaches, group processes and educational designs. In Handbook of research on educational communications and technology (pp. 439-451). Springer, New York, NY.

Hofer, Andreas. 2012. "Mashups - mit einfachen Techniken zum eigenen Web 2.0". Praxisbuch Web 2.0 im Fremdsprachenunterricht. Ed. Jürgen Wagner. (e-learning). Boizenburg: Hülsbusch. 103-11.

Hyland, K. (2016). Teaching and researching writing (3rd edn.). New York: Routledge.

Jeong, H., \& Hmelo-Silver, C. E. (2016). Seven affordances of computer-supported collaborative learning: How to support collaborative learning? How can technologies help?. Educational Psychologist, 51(2), 247-265.

Johnson, D. W., \& Johnson, R. T. (1986). Computer-assisted cooperative learning. Educational Technology, 26(1), 12-18.

Kessler, Greg, Dawn Bikowski, and Jordan Boggs. (2012). “Collaborative writing among second language learners in academic web-based projects". Language Learning \& Technology 16.1: 91-109.

Koenig, K., Zydney, J. M., Behr, D., \& Bao, L. (2017). Enhancing a scientific inquiry lesson through computer-supported collaborative learning. Science Scope, 41(1), 80.

Kwon, K., Liu, Y. H., \& Johnson, L. P. (2014). Group regulation and social-emotional interactions observed in computer supported collaborative learning: Comparison between good vs. poor collaborators. Computers \& Education, 78, 185-200.

Li, M., \& Kim, D. (2016). One wiki, two groups: Dynamic interactions across ESL collaborative writing tasks. Journal of second language writing, 31, 25-42.

Li, M., \& Zhu, W. (2016). Explaining dynamic interactions in wiki-based collaborative writing. 
Li, X., Chu, S. K., Ki, W. K., \& Woo, M. A. T. S. U. K. O. (2011). Students and teacher's attitudes and perceptions toward a Wiki-based collaborative process writing pedagogy in a primary five Chinese classroom. In CITE Research Symposium, CITERS 2011. The University of Hong Kong.

Lin, H. (2014). Establishing an empirical link between computer-mediated communication and SLA: A meta-analysis. Language Learning \& Technology, 18(3), 120-147. https://dx.doi.org/10125/44387

Littleton, K. (1999). Learning together: Understanding the processes of computer-based collaborative learning. Collaborative Learning-Cognitive and Computational Approaches.

Liu, S. H. J., \& Lan, Y. J. (2016). Social constructivist approach to web-based EFL learning: Collaboration, motivation, and perception on the use of Google docs. Educational Technology \& Society, 19(1), 171-186.

McConnell, D. (2014). Implementing computing supported cooperative learning. Routledge.

McDonough, K., \& García Fuentes, C. (2015). Writing to learn language: The effect of writing task on Colombian EFL learners' language use. TESL Canada Journal, 32(2), 67e79.

McDonough, K., De Vleeschauwer, J., \& Crawford, W. (2018). Comparing the quality of collaborative writing, collaborative prewriting, and individual texts in a Thai EFL context. System, 74, 109-120.

Mudawe, O. M. N. (2018). Google Docs: Potentials and Promises for Scaffolding Supervisory Pedagogical Practices of EFL/ESL Students' Writing Dissertation. Journal of Applied Linguistics and Language Research, 5(2), 192-206.

Newman, D. R., Johnson, C., Webb, B., \& Cochrane, C. (1997). Evaluating the quality of learning in computer supported co-operative learning. Journal of the American Society for Information science, 48(6), 484-495.

Newman, D. R., Webb, B., \& Cochrane, C. (1995). A content analysis method to measure critical thinking in face-to-face and computer supported group learning. Interpersonal Computing and Technology, 3(2), 56-77.

Beatty, K., \& Nunan, D. (2004). Computer-mediated collaborative learning. System, 32(2), 165183.

Li, M. (2018). Computer-mediated collaborative writing in L2 contexts: An analysis of empirical research. Computer Assisted Language Learning, 31(8), 882-904.

Seyyedrezaie, Z. S., Ghonsooly, B., Shahriari, H., \& Fatemi, H. H. (2016). Mixed methods analysis of the effect of Google Docs environment on EFL Learners' writing performance and causal attributions for success and failure. Turkish Online Journal of Distance Education (TOJDE), 17, 90-110. Retrieved from http://dergipark.ulakbim.gov.tr/tojde/article/viewFile/5000196874/5000170473

Sharples M., Goodlet J.S., Beck E.E., Wood C.C., Easterbrook S.M., Plowman L. (1993) Research Issues in the Study of Computer Supported Collaborative Writing. In: Sharples M. (eds) Computer Supported Collaborative Writing. Computer Supported Cooperative Work. Springer, London

Steinberger, F. (2017). Synchronous collaborative L2 writing with technology (Doctoral dissertation, Imu).

Storch, N. (2002). Patterns of interaction in ESL pair work. Language Learning, 52(1), 119-158. doi: 10.1111/1467-9922.00179

Storch, N. (2005). Collaborative writing: Product, process, and students' reflections. Journal of Second Language Writing, 14(3), 153-173. doi:10.1016/j.jslw.2005.05.002 
Storch, N. (2012). Collaborative writing as a site for L2 learning in face-to-face and online modes. In G. Kessler, A. Oskoz, \& I. Elola (Eds.), Technology across writing contexts and tasks. San Marcos, TX: CALICO.

Storch, N. (2013). Collaborative writing in L2 classrooms. Bristol, UK: Multilingual Matters.

Storch, N. (2013). Collaborative writing in L2 classrooms. Bristol, UK: Multilingual Matters.

Storch, N. E. O. M. Y., \& Wigglesworth, G. I. L. L. I. A. N. (2007). Writing tasks: The effects of collaboration. Investigating tasks in formal language learning, 157-177.

Streetman, R. R. (2018). The Effects of Computer-Supported Collaborative Learning on Sense of Connectedness, Sense of Learning, and Overall Sense of Community among High School Students Enrolled in a Marketing Course.

Strobl, C. (2014). Affordances of web 2.0 technologies for collaborative advanced writing in a foreign language. CALICO JOURNAL, (1), 1-18.

Suwantarathip, O., \& Wichadee, S. (2014). The Effects of Collaborative Writing Activity Using Google Docs on Students' Writing Abilities. Turkish Online Journal of Educational Technology-TOJET, 13(2), 148-156.

Swain, M. (1995). Three functions of output in second language learning. In G. Cook \& B. Seidlhofer (Eds.), Principle and practice in applied linguistics: Studies in honor of H.G. Widdowson (pp. 125-144). Oxford, UK: Oxford University Press.

Swain, M., \& Lapkin, S. (1998). Interaction and second language learning: Two adolescent French immersion students working together. Modern Language Journal, 82, 320-337.

Vandergriff, I. (2016). Second-language discourse in the digital world: Linguistic and social practices in and beyond the networked classroom. Amsterdam: John Benjamins

Wang, Y. C. (2015). Promoting collaborative writing through wikis: A new approach for advancing innovative and active learning in an ESP context. Computer Assisted Language Learning, 28(6), 499-512.

Wigglesworth, G., \& Storch, N. (2009). Pair versus individual writing: Effects on fluency, complexity and accuracy. Language Testing, 26(3), 445-466.

Yim, S. (2017). Digital Literacy in Academic Settings: Synchronous Collaborative Writing among Linguistically Diverse Students DISSERTATION (Doctoral dissertation, University of California, Irvine).

Zhang, H., Song, W., Shen, S., \& Huang, R. (2014). The effects of blog-mediated peer feedback on learners' motivation, collaboration, and course satisfaction in a second language writing course. Australasian Journal of Educational Technology, 30(6).

Zhou, W., Simpson, E., \& Domizi, D. P. (2012). Google docs in an out-of-class collaborative writing activity. International Journal of Teaching and Learning in Higher Education, 24, 359-375. Retrieved from http://files.eric.ed.gov/fulltext/EJ1000688.pdf

Zhu, C. (2012). Student satisfaction, performance, and knowledge construction in online collaborative learning. Educational Technology \& Society, 15, 127-136. Retrieved from http://www.jstor.org/stable/jeductechsoci.15.1.127

Zou, B., Wang, D., \& Xing, M. (2016). Collaborative tasks in wiki-based environment in EFL learning. Computer Assisted Language Learning, 29(5), 1001-1018. 